\title{
A COMMUNITY BASED STUDY ON INFANT AND YOUNG FEEDING PRACTICES IN A RURAL AREA OF KARNATAKA.
}

\author{
Dr. Sharvanan Udayar E. Dr. Angadi M. M, Dr. Rekha Udgiri, Dr. Santosh Patil D.
}

\author{
1. Assistant Professor, Department of Community Medicine, PES Institute of Medical Science and Research, \\ Kuppam. \\ 2. Professor \& HOD, Department of Community Medicine, BLDEU's Shri B. M. Patil Medical College, Bijapur. \\ 3. Professor, Department of Community Medicine, Shri. B. M. Patil Medical College, Bijapur. \\ 4. Assistant Professor, Department of Community Medicine, Shri B. M. Patil Medical College, Bijapur.
}

\section{CORRESPONDING AUTHOR:}

Dr. Sharvanan. E,

PES Institute of Medical Science and Research,

Kuppam, Chittoor Dist, Andhra Pradesh-517425,

E-mail: saravananudayar83@gmail.com,

Ph: $09618292770 / 08095515455$.

ABSTRACT: BACKGROUND: Adequate nutrition during infancy and early childhood is critical to the development of children's full human potential. OBJECTIVE: The main objective was to assess the Infant and Young Child Feeding (IYCF) practices and associated socio demographic variables among children aged less than two years in rural areas METHODS: A community based, cross sectional descriptive study was done during Sept 09-Aug 2010 which is the rural field practice area of Shri. B. M. Patil Medical College SBMPMC. The data was computed and analyzed using SPSS statistical package (version 13.0). RESULTS: During the study period 264 mothers of infants and young children interviewed with the questionnaire and 159 out of 264 had received prelacteal feeds (males $64 \%$ and females56.3\%). Illiterate mothers (69.7\%) practiced more prelacteal feeding than the literate mothers (54.6\%). 36\% received exclusive breast feeding for a period six months. Majority of the illiterate mothers were practicing early (31.4\%) and delayed weaning (32.5\%).Poor socioeconomic status, illiteracy, birth spacing and cultural beliefs had significant effect on infant and young children feeding practices. CONCLUSIONS: The study re-emphasized the need for conducting continued infant and child feeding intervention programmes especially for the mother during antenatal and postnatal checkups.

KEY WORDS: Exclusive breast feeding, Weaning, Infant and Young children.

INTRODUCTION: Adequate nutrition during infancy and early childhood is critical to the development of children's full human potential. Poor Infant and Young Child Feeding (IYCF) practices, coupled with high rates of infectious diseases, are the proximate causes of malnutrition during the first two years of life. The second half of an infant's first year is an especially vulnerable time, when breast milk alone is no longer sufficient to meet his or her nutritional requirements and complementary feeding should start ${ }^{1}$. Of the 19 million infants in the developing world who have low birth weight $(<2,500$ grams), 8.3 million are in India. This means that approximately 43 per cent of all the world's infants who are born with a low birth weight are born in India. Malnutrition is an underlying cause in up to 50 per cent of all underfive deaths. About 55 million, or one-third, of the world's underweight children under age five live in India. 
Children need complementary foods in addition to breast milk from the age of six months. In India, common problems include the provision of poor quality complementary foods, insufficient amounts of complementary foods, insufficient breastfeeding, detrimental feeding practices, and contamination of complementary food and feeding utensils. In addition, if complementary foods are given too early or too frequently, they displace breast milk, which is of higher nutritional value than other foods. Various social, economic and cultural factors in rural areas will also influence the IYCF practices 2 .

The timely introduction of complementary feeding can prevent almost $6 \%$ of under-five mortality. It was estimated that, if $90 \%$ of infants are covered with a package of intervention to protect, promote, and support the optimal IYCF practices, almost one-fifth of overall under-five mortality can be averted. The World Health Organization (WHO) and other various international agencies recommended exclusive breastfeeding for the first six months of life with early initiation and continuation of breastfeeding for two years or more together with nutritionally-adequate, safe, age-appropriate complementary feeding starting at six months ${ }^{3}$. With this background, the present study was undertaken to assess the IYCF practices and associated socio demographic variables among children aged less than two years in rural areas of Bijapur, District, Karnataka.

METHODS: A community-based, cross-sectional descriptive study was conducted in Shivanagi during Sept 09-Aug 2010 which is the rural field practice area of Shri B.M.Patil Medical College, situated $27 \mathrm{~km}$ away from Bijapur and has population of $7060 .{ }^{4} \mathrm{~A}$ house to house survey was done and mothers with children aged less than two years were included in the study. Those who were not permanent residents and not willing to participate were excluded and Modified B.G.Prasad socioeconomic classification ${ }^{5}$ was used classifying socioeconomic status.

ETHICS: The Institutional Ethics Committee of the Shri B.M.Patil Medical College approved the study.

STATISTICS: Analysis was done using the SPSS software (version 13.0), Simple proportions were calculated for each IYCF practice. The differences in the feeding practices and sociodemographic variables if any were noted using chi-square test.

RESULTS: In the present study 264 infants and young children up to 2 years were studied of whom 136 were males and 128 were females.159 out of 264 had received prelacteal feeds (males $64 \%$ and females 56.3\%).Illiterate mothers (69.7\%) practiced more prelacteal feeding than the literate mothers (54.6\%) and the observed difference according to education of the mother was not statistically significant in our study $(\mathrm{p}=0.015) .53 .3 \%$ of nuclear families were giving more prelacteal than three generation (62\%) and joint family (63\%) (Table1).

However the difference in type of family and prelacteal practices was not statistically significant in our study $(\mathrm{p}=0.38)$. The study also found that the practice of prelacteal feeding was more prevalent in lower socioeconomic group than in higher class and this difference was found to be statistically significant $(\mathrm{P}<0.001)$.

Only 36\% received exclusive breast feeding for a period six months and less than half of the infants and young children belonged to Hindu and Muslim families received exclusive breast feeding, literate mothers (41.9\%) were more aware about it as compared to illiterate mothers(26.3\%).Statistically significant difference was observed according to socioeconomic 
status and exclusive breastfeeding $(\mathrm{p}<0.001)$.Similarly with the birth interval $(\mathrm{p}=0.07)$ (Table 2).

With respect to weaning, majority of the illiterate mothers were practicing early (31.4\%) and delayed weaning (32.5\%). Only literate mothers (56.9\%) initiated it at the age of 6 months as per the WHO guidelines ${ }^{5}$. Poor socioeconomic status $(\mathrm{p}=0.001)$ and birth interval $(p=0.002)$ also had an effect on initiation of weaning.

DISCUSSION: In our study more than half of the infants and young children had received prelacteal feeds and it was high in children with illiterate mothers belonging to poor socioeconomic status and most important reason for this was family customs and relatives advice. Similar findings were observed in a study by Devang raval ${ }^{6}(2001)$ in which $61.9 \%$ of infants had received prelacteal feeds. According to NFHS-3 report ${ }^{7}$ (2005-2006) 57\% newborns received prelacteal feeds $(57.3 \%$ male and $57 \%$ female) and $67.5 \%$ of the illiterate mothers gave prelacteal feeds. Saurav et $\mathrm{al}^{8}(2003)$ also reported similar findings.

Exclusive breastfeeding by mothers as derived from our study is much lower than the values reported by Devang raval ${ }^{6}$, Chatterjee Saurav et $\mathrm{l}^{8}$ and however this when compared to study by Vyas Shaili et al ${ }^{9}$ in rural areas of Uttarakhand was much higher. This may be because of the low literacy levels and customs and many of the mothers gave reasons as insufficient breast milk and could not able to feed during illness.

Majority of the mothers practiced early and delayed weaning and this trend observed higher among illiterate mothers. The findings from the present study clearly highlights the importance of educating the women on infant and child feeding practices and the knowledge may be imparted even at the school or college level. The Government of India recommends that children should be exclusively breastfed for the first six months of life (that is, they should be given only breast milk with no other liquids or food). There are many reasons for recommending exclusive breastfeeding for the first six months. First, breast milk is nutritionally superior to other liquids and solid foods. Second, when a child consumes other liquids and solid foods, the intake of breast milk is reduced, which in turn decreases the mother's supply of milk. Third, feeding young infants liquids and solid foods increases their exposure to pathogens, putting them at greater risk of contracting diarrhoeal disease. There is also need for conducting infant and child feeding intervention programmes especially for the mother during antenatal and postnatal checkups.

Practices such as early or delayed inititation of weaning should be discouraged and women organizations need to be associated for active dissemination of information on infant and child feeding practices to educationally deprived women. 
Table 1: Distribution of Prelacteal feed practices in infants and young children $(n=264)$.

\begin{tabular}{|c|c|c|c|c|}
\hline \multicolumn{2}{|c|}{ Parameters } & $\begin{array}{c}\text { Prelacteal } \\
\text { feed given } n=159 \\
\text { percent }(60.3 \%)\end{array}$ & $\begin{array}{c}\text { Prelacteal } \\
\text { feed not given } \\
\text { n=105 percent } \\
(30.7 \%)\end{array}$ & $\begin{array}{l}\text { Chi } \\
\text { square }\end{array}$ \\
\hline Gender & $\begin{array}{c}\text { Male136 (51.8) } \\
\text { Female128 (48.2) }\end{array}$ & $\begin{array}{l}87(64.0) \\
72(56.3)\end{array}$ & $\begin{array}{l}49(36.0) \\
56(43.7)\end{array}$ & $\begin{array}{c}\text { Chi } \\
\text { sq.:1.61 } \\
\mathrm{p}=0.2\end{array}$ \\
\hline Religion & $\begin{array}{l}\text { Hindu } 236 \text { (89.7) } \\
\text { Muslim28 (10.3) }\end{array}$ & $\begin{array}{l}147(62.3) \\
12(43.0)\end{array}$ & $\begin{array}{l}89(37.7) \\
16(57.0)\end{array}$ & $\begin{array}{c}\text { Chi } \\
\text { sq.:3.99 } \\
\mathrm{p}=0.04\end{array}$ \\
\hline $\begin{array}{l}\text { Education } \\
\text { of Mother }\end{array}$ & $\begin{array}{l}\text { Illiterate99 (37.5) } \\
\text { Literate165 (62.5) }\end{array}$ & $\begin{array}{l}57(69.7) \\
82(54.6)\end{array}$ & $\begin{array}{l}42(30.3) \\
83(45.4)\end{array}$ & $\begin{array}{c}\text { Chi sq.: } \\
\begin{array}{c}1.6 \\
\text { p }>0.5\end{array}\end{array}$ \\
\hline Type of Family & $\begin{array}{l}\text { Nuclear } 62(23.5) \\
\text { 3gene } 105(40.0) \\
\text { Joint } 97(36.5)\end{array}$ & $\begin{array}{l}33(53.0) \\
65(62.0) \\
61(63.0)\end{array}$ & $\begin{array}{l}29(47.0) \\
40(38.0) \\
36(37.0)\end{array}$ & $\begin{array}{c}\text { Chi sq.: } \\
1.68 \\
p=0.43\end{array}$ \\
\hline $\begin{array}{c}\text { Socio } \\
\text { Economical class }\end{array}$ & $\begin{array}{c}\text { Class I } 7 \text { (2.90) } \\
\text { Class II } 7 \text { (2.9) } \\
\text { Class III } 66(25.10) \\
\text { Class IV } 89(33.75) \\
\text { Class V } 95(35.40)\end{array}$ & $\begin{array}{r}2(28.6) \\
6(85.8) \\
23(34.9) \\
63(70.8) \\
65(68.4)\end{array}$ & $\begin{array}{r}5(71.4) \\
1(14.2) \\
43(65.1) \\
26 .(29.2) \\
30(31.6)\end{array}$ & $\begin{array}{l}\text { Chi } \\
\text { sq: } 24.64 \\
\text { p }<0.001\end{array}$ \\
\hline
\end{tabular}


Table 2: Distribution of exclusivebreastfeeding practices in infants and young children $(n=264)$.

\begin{tabular}{|c|c|c|c|c|}
\hline \multicolumn{2}{|c|}{ Parameters } & $\begin{array}{c}\text { EBF given } \\
\text { n=95 percent } \\
(36.0 \%)\end{array}$ & $\begin{array}{c}\text { EBF not given } \\
\text { n=169 percent } \\
(64.0 \%)\end{array}$ & Chi square \\
\hline Gender & $\begin{array}{l}\text { Male136 (51.8) } \\
\text { Female128 (48.2) }\end{array}$ & $\begin{array}{l}40(29.4) \\
55(42.3) \\
\end{array}$ & $\begin{array}{l}96(70.6) \\
73(57.7) \\
\end{array}$ & $\begin{array}{l}\text { Chi sq.:5.4 } \\
\qquad p=0.02\end{array}$ \\
\hline Religion & $\begin{array}{l}\text { Hindu } 236 \text { (89.7) } \\
\text { Muslim28 (10.3) }\end{array}$ & $\begin{array}{r}87(36.9) \\
8(28.6)\end{array}$ & $\begin{array}{l}149(63.1) \\
20(71.4)\end{array}$ & $\begin{array}{l}\text { Chi sq.:0.68 } \\
\qquad p=0.38\end{array}$ \\
\hline $\begin{array}{l}\text { Education } \\
\text { of Mother }\end{array}$ & $\begin{array}{l}\text { Illiterate99 (37.5) } \\
\text { Literate165 (62.5) }\end{array}$ & $\begin{array}{l}29(26.3) \\
66(41.9)\end{array}$ & $\begin{array}{l}70(73.7) \\
99(58.1)\end{array}$ & $\begin{array}{c}\text { Chi sq.: } 3.06 \\
\quad P=0.07\end{array}$ \\
\hline Type of Family & $\begin{array}{l}\text { Nuclear } 62(23.5) \\
\text { 3gene } 105(40.0) \\
\text { Joint } 97(36.5)\end{array}$ & $\begin{array}{l}24(38.7) \\
32(30.5) \\
39(40.2)\end{array}$ & $\begin{array}{l}38(61.3) \\
73(69.5) \\
58(59.8)\end{array}$ & $\begin{array}{l}\text { Chi sq.: } 2.33 \\
\quad p=0.31\end{array}$ \\
\hline $\begin{array}{l}\text { Socio } \\
\text { Economical class }\end{array}$ & $\begin{array}{l}\text { Class I } 7 \text { (2.90) } \\
\text { Class II } 7 \text { (2.9) } \\
\text { Class III } 66(25.10) \\
\text { Class IV } 89(33.75) \\
\text { Class V } 95(35.40)\end{array}$ & $\begin{array}{r}2(28.5) \\
5(71.4) \\
38(57.6) \\
23(25.9) \\
29(30.6)\end{array}$ & $\begin{array}{c}5(71.5) \\
2(28.6) \\
28(42.4) \\
66(74.1) \\
66(69.4)\end{array}$ & $\begin{array}{c}\text { Chi sq: } 19.9 \\
\text { p<0.001 }\end{array}$ \\
\hline Birth interval & $\begin{array}{l}<1 \text { yr } 45(17.3) \\
1-2 \text { yr } 143(54.3) \\
>3 y r s 76(28.4)\end{array}$ & $\begin{array}{l}28(62.2) \\
51(35.7) \\
34(44.8)\end{array}$ & $\begin{array}{l}17(37.8) \\
92(64.3) \\
42(55.2)\end{array}$ & $\begin{array}{l}\text { Chi sq: } 10.0 \\
p=0.007\end{array}$ \\
\hline
\end{tabular}




\section{REFERENCES:}

I. Improving Complementary Feeding Practices: A Review of Evidence from South Asia . Evidence review series march 2008; Available from http://www.intrahealth.org/ intrahea/files/media/maternal-neonatal-and-childrenshealthfamily-planning/ER Brief CF\%202.pdf.

II. Cooperative for Assistance and Relief Everywhere(CARE). Infant and Young Child Feeding Practices. Collecting and Using Data: A Step-by-Step Guide.2010.Available from http://windowofopp.files.wordpress.com/2010/12/final-iycf-guide-iycf-practices.pdf.

III. Apurba S, Dipta KM, Tanmay KP, Asit BS, Nirmal KM, Akhil BB. Infant and Young Child feeding Practices in Bankura District, West Bengal, India. J Health Popul Nutr 2010Jun;28(3):294-299.

IV. Govt.of India (2001).Census of India 2001, Provisional Population Totals, Paper-1 of 2001.

V. Insurance worker volume XLVII, No.12, Dec 2008 and Insurance worker volume XLVIII No. 10, Oct 2009.

VI. World Health Organization (WHO). Maternal, newborn, child and adolescent health: Indicators for assessing infant and young child feeding practices - part I: definition; 2008.

Availablefromhttp://www.who.int/maternaments/9789241596664/en/l child adolesc ent/docu.Accessed latest on 28-08-2012.

VII. Devang R, Jankar DV, Singh MP. A study of breast feeding practices among infants living in slums of Bhavnagar city, Gujarat, India. healthline Jul-Dec 2011; 2(2):73-82.

VIII. National Family Health Survey 2005-2006 (NFHS-3). Mumbai: International Institute of Population Sciences.Available from: http://www.nfhsindia.org.

IX. Chatterjee Saurav , Saha Sandhita: A study on KP of mothers regarding infant feeding and nutritional status of Under 5 children attending immunization clinic of Medical college 2008.Avalable from http://www.ispub.com/journal/the-internet-journal-ofnutrition-and-wellness/archives.html.Accessed latest on 29-08-2012.

X. Vyas S, Sharma P, Kandpal S D, Semwal J, Srivastava A, Nautiyal V. A community based study on breastfeeding practices in a rural area of Uttarakhand. National J Commuity Med Apr-jun2012;3(2):283-287. 